\title{
Endoscopic Treatment of Pancreatic Fluid Collections
}

\author{
Michal Kloska \\ Lehigh Valley Health Network \\ (D) https://orcid.org/0000-0001-7382-0630 \\ Corresponding author: michalkloska@gmail.com \\ Shashin Shah \\ Department of Gastroenterology, Lehigh Valley \\ Health Network, Allentown, Pennsylvania, USA \\ (iD) https://orcid.org/0000-0003-0561-5613 \\ Hiral N. Shah \\ Department of Gastroenterology, Lehigh Valley \\ Health Network, Allentown, Pennsylvania, USA \\ (iD) https://orcid.org/0000-0001-8507-9798
}

DOI: https://doi.org/10.20883/medical.e443

Keywords: acute pancreatitis, plastic stent, lumen apposing metal stent

Published: 2020-06-30

How to cite: Kloska M, Shah S, Shah HN. Endoscopic Treatment of Pancreatic Fluid Collections. JMS [Internet]. 2020 Jun 30;89(2):e443. doi:10.20883/medical.e443

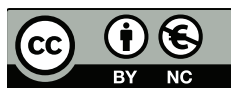

(C) 2020 by the author(s). This is an open access article distributed under the terms and conditions of the Creative Commons Attribution (CC BY-NC) licencse. Published by Poznan University of Medical Sciences

\begin{abstract}
Acute pancreatitis is frequently complicated by pancreatic fluid collections (PFCs), which usually resolve spontaneously but some can mature forming large cysts filled with fluid or necrotic debris. Historically, they have been surgically removed but with the advancement of endoscopic procedures, endoscopic drainage has emerged as a safe first-line treatment of PFCs. Furthermore, the development of plastic stents and lumen apposing metal stents (LAMS) has replaced not only open surgery but also the percutaneous drainage due to fewer adverse events. In particular, the LAMS has gained favour recently as large meta-analysis suggested their advantages over plastic stents in the treatment of PFCs, however, data regarding their use in the drainage of PFCs are still scarce.
\end{abstract}

\section{Introduction}

Pancreatic fluid collections (PFCs) are common complications of acute pancreatitis $n$ over $40 \%$ of patients [1]. evised Atlanta criteria categorie PFCs as acute $(<4$ weeks after episode of pancreatitis) or chronic ( $>4$ weeks after episode of pancreatitis), which are further subdivided by the presence or absence of necrosis in the fluid collection. acute PFCs are acute peripancreatic fluid collections (APFCs) that do not have a defined wall and are reabsorbed spontaneously within several weeks. The remainder form acute necrotic collections (ANCs) consist of a combination of necrotic tissue and variable amount of fluid. ifferentiation between the two is difficult sequential imaging is often required. These PFCs can mature and form a capsule leading to creation of pancreatic pseudocysts (PP) and walled-off pancreonecrosis (WOPN) respectively [2]. Traditionally, large PP, WOPN or infected necroti pancreatitis can be treated with open necrosctomy with a recent tendency towards step up surgical approach based on percutaneous or endoscopic drainage. These minimally invasive procedures are associated with decreased mortality, multiorgan failures, and long term pancreatic endocrine and exocrine insufficiency [3,4]. Studies also attempted to compare the outcomes of percutaneous and endoscopic drainagedifference 
in major complications or mortality between the two methods demonstrated, however, the percutaneous approach was complicated with an increased inflammatory respone, higher rate of pancreatic fistulas and longer hospital stay $[5,6]$. With furher advances in endoscopic procedures and the development of plastic stents (PS) and more recently, lumen aposing metal stents (LAMS), endoscopic drainage has become widely regarded as a safe first-line therapy for patient with necrotic or infected PFC, symptomatic PP that are anatomically amenable to drainage.

PS were the first utili in transmural endoscopic drainage of PFCs. Initially gastroscopic evaluation performed to identify PFCs by extrinsic bulging compressing the gastric lumen. Afterwards multiple PS could be positioned transmuraly with placement with endoscopic and fluoroscopic guidance. This approach has evolved with the development of endoscopic ultrasound (EUS) as the PFCs could be directly visuali allowing for more precise stent placement, thereby associated with decreased number of complications. PS have been proven effective for drainage of PP with complete resolution of the PFCs in $8293 \%$ of cases with cyst reoccurrence [7-10]. Nevertheless, EUS assisted PFCs drainage with the use of PS is associated with multiple complications including acute bleeding episodes, stent occlusions or migration, infection and perforation that occur in $240 \%$ of patients [11]. Although intervention with PS have proven to be effective in the treatment of fluidfilled cysts, WOPN cavities with more solid debris have led to increased risk of stent obstruction due to small diameter of PS [12].

Monumental advances to endoscopic intervention of PFCs arrived with the development of LAMS. These stents are similarly placed across luminal structures to create gastro-pancreatic connection. LAMS are tubularshaped biflanged which allows proper anchoragedecreas the risk of migration (Figure 1). Placement of LAMS has allowed for more efficient drainage of PFCs due to the larger diameter size while allowing direct interrogation of the cyst cavity through the stent and subsequent intervention such us necrosectomy. This is usually performed in WOPN with large necrotic component, in infected necroses or infected fluid collections [13].

There are multiple LAMS currently available on the marketAxios (Boston Scientific, USA)

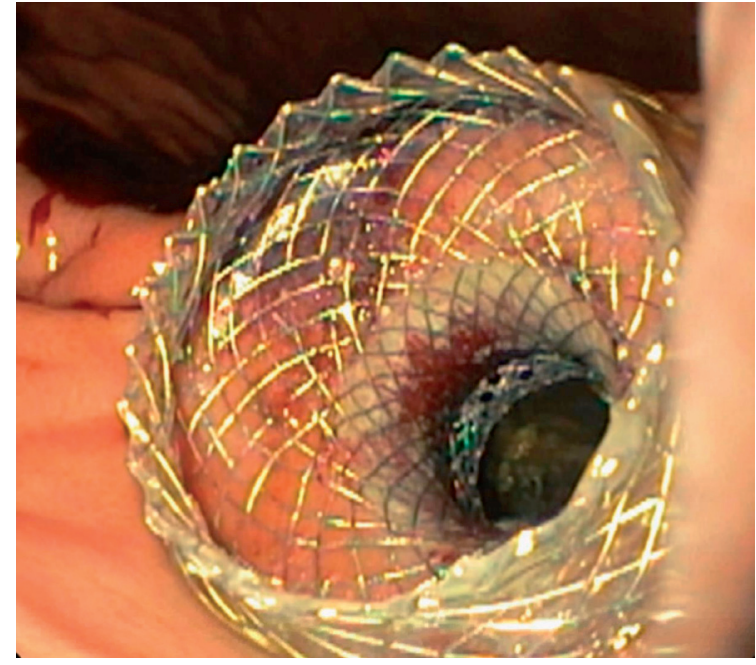

Figure 1. Endoscopic view of LAMS

Hanaro (M.I Tech, South Korea), Nagi and Spaxus (Taewong Medical, South Korea), Aix PPS (Leufen Medical, Germany), that vary in length (from $5 \mathrm{~mm}$ to $30 \mathrm{~mm}$ ) and diameter (from $8 \mathrm{~mm}$ to $16 \mathrm{~mm}$ ) (Figure 2). Initial studies have not shown benefits of LAMS over PS in PP and LAMS were believed to have more indications in the setting of WOPN, yet many studies revealed contradict results. However, large metaanalysis of Yoon (PP 250 patients, WOPN 555 patients) provided data the more frequent use of LAMS as they demonstrated higher technical and clinical success rate with dverse events after LAMS placement compared to PS.

Recent large meta-analysis of 14 studies from 2012 to 2016 that included 812 patients (608 WOPN, 204 PP) demonstrated high technical and clinical success rate of LAMS in the treatment of PFCs. LAMS were successfully placed in $98.9 \%$ and resolution of patient symptoms with at least $50 \%$ size reduction of PFCs was accomplished in over $90 \%$ of patients with WOPN. In the treatment of PP the technical and clinical success was even higher, respectively in $97 \%$ and $98 \%$ of patients. Unfortunately, $10.1 \%$ of patients developed complicationsoccurred early and included infections (3.6\%), bleeding (3.3\%) or stent migration (1.9\%). Fortunately, major events as perforations occurred in $0.6 \%$ of patients [14]. Our data also demonstrated promising outcomes, as none of the 43 patients with PFCs treated with LAMS developed any major complications and adverse events were mostly limited to minor acute bleeding episodes resolving after cauteri (4.7\%) or stent migrations (7.0\%) [15]. 


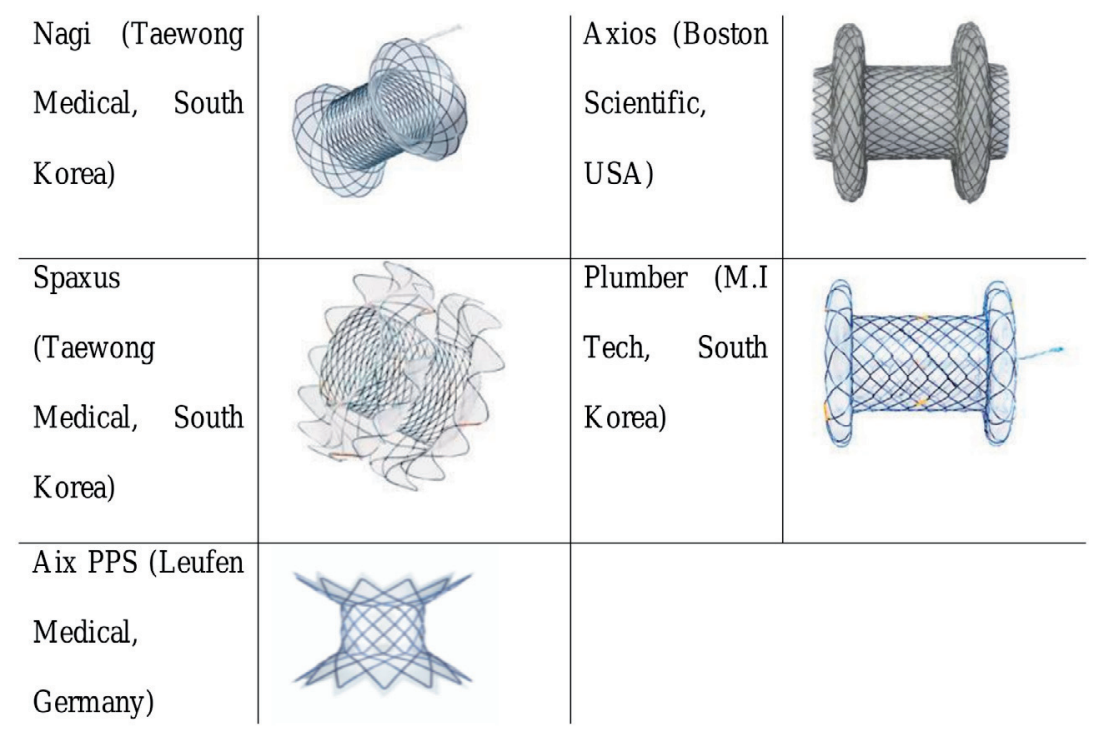

Figure 2. Currently available LAMS

The newest modification, adopted by advanced endoscopists in 2015, led to integration of LAMS with electrocautery enhanced delivery system that enables advancement of the stent using cautery instead of prior dilation. This has resulted in reduced risk of malposition, leakage and is very cost [16].

In conclusion, with the advancements of endoscopic procedures, this minimally invasive approach using PS and LAMS becme mainstay of treatment of PFCs. The endoscopic approach associated with decreased mortality and morbidity over a surgical approachadverse events tha percutaneous drainage. The development of LAMS approach as recent data suggests advantages over PS in the treatment of PFCs but further randomi controlled trials are needed.

\section{Acknowledgements}

\section{Conflict of interest statement}

The authors declare no conflict of interest.

\section{Funding sources}

There are no sources of funding to declare.

\section{References}

1. Cui ML, Kim KH, Kim HG, Han J, Kim H, Cho KB, Jung MK, Cho CM, Kim TN. Incidence, Risk Factors and Clinical Course of Pancreatic Fluid Collections in Acute Pancreatitis. Digestive Diseases and Sciences. 2013 Dec 11;59(5):1055-1062. https://doi. org/10.1007/s10620-013-2967-4
2. Banks PA, Bollen TL, Dervenis C, Gooszen HG, Johnson CD, Sarr MG, Tsiotos GG, Vege SS. Classification of acute pancreatitis-2012: revision of the Atlanta classification and definitions by international consensus. Gut. 2012 Oct 25;62(1):102-111. https://doi. org/10.1136/gutjnl-2012-302779

3. van Santvoort HC, Besselink MG, Bakker OJ, Hofker HS, Boermeester MA, Dejong $\mathrm{CH}$, van Goor $\mathrm{H}$, Schaapherder $A F$, van Eijck $\mathrm{CH}$, Bollen $\mathrm{TL}$, van Ramshorst B, Nieuwenhuijs VB, Timmer R, Laméris JS, Kruyt PM, Manusama ER, van der Harst E, van der Schelling GP, Karsten T, Hesselink EJ, van Laarhoven CJ, Rosman C, Bosscha K, de Wit RJ, Houdijk AP, van Leeuwen MS, Buskens E, Gooszen HG. A Stepup Approach or Open Necrosectomy for Necrotizing Pancreatitis. New England Journal of Medicine. 2010 Apr 22;362(16):1491-1502. https://doi.org/10.1056/ nejmoa0908821

4. Hollemans RA, Bakker OJ, Boermeester MA, Bollen $\mathrm{TL}$, Bosscha K, Bruno MJ, Buskens $\mathrm{E}$, Dejong $\mathrm{CH}$, van Duijvendijk $P$, van Eijck $\mathrm{CH}$, Fockens $\mathrm{P}$, van Goor $H$, van Grevenstein WM, van der Harst E, Heisterkamp J, Hesselink EJ, Hofker S, Houdijk AP, Karsten T, Kruyt $\mathrm{PM}$, van Laarhoven CJ, Laméris JS, van Leeuwen MS, Manusama ER, Molenaar IQ, Nieuwenhuijs VB, van Ramshorst B, Roos D, Rosman C, Schaapherder AF, van der Schelling GP, Timmer R, Verdonk RC, de Wit RJ, Gooszen HG, Besselink MG, van Santvoort HC. Superiority of Step-up Approach vs Open Necrosectomy in Long-term Follow-up of Patients With Necrotizing Pancreatitis. Gastroenterology. 2019 Mar;156(4):10161026. https://doi.org/10.1053/j.gastro.2018.10.045

5. van Brunschot S, van Grinsven J, van Santvoort HC, Bakker OJ, Besselink MG, Boermeester MA, Bollen $\mathrm{TL}$, Bosscha K, Bouwense SA, Bruno MJ, Cappendijk VC, Consten EC, Dejong $\mathrm{CH}$, van Eijck $\mathrm{CH}$, Erkelens WG, van Goor $\mathrm{H}$, van Grevenstein WMU, Haveman J, Hofker SH, Jansen JM, Laméris JS, van 
Lienden KP, Meijssen MA, Mulder CJ, Nieuwenhuijs VB, Poley J, Quispel R, de Ridder RJ, Römkens TE, Scheepers JJ, Schepers NJ, Schwartz MP, Seerden T, Spanier BWM, Straathof JWA, Strijker M, Timmer $R$, Venneman NG, Vleggaar FP, Voermans RP, Witteman BJ, Gooszen HG, Dijkgraaf MG, Fockens $\mathrm{P}$, Manusama ER, Hadithi M, Rosman C, Schaapherder AF, Schoon EJ. Endoscopic or surgical step-up approach for infected necrotising pancreatitis: a multicentre randomised trial. The Lancet. 2018 Jan;391(10115):51-58. https://doi.org/10.1016/ s0140-6736(17)32404-2

6. Bakker OJ, van Santvoort HC, van Brunschot S, Geskus RB, Besselink MG, Bollen TL, van Eijck $\mathrm{CH}$, Fockens P, Hazebroek EJ, Nijmeijer RM, Poley J, van Ramshorst B, Vleggaar FP, Boermeester MA, Gooszen HG, Weusten BL, Timmer R, Dutch Pancreatitis Study Group. Endoscopic Transgastric vs Surgical Necrosectomy for Infected Necrotizing Pancreatitis. JAMA. 2012 Mar 14;307(10):1053. https://doi.org/10.1001/ jama.2012.276

7. Kahaleh M, Shami V, Conaway M, Tokar J, Rockoff T, De La Rue S, de Lange E, Bassignani M, Gay S, Adams $R$, Yeaton P. Endoscopic Ultrasound Drainage of Pancreatic Pseudocyst: A Prospective Comparison with Conventional Endoscopic Drainage. Endoscopy. 2006 Apr;38(4):355-359. https://doi.org/10.1055/s2006-925249

8. Cremer M, Deviere J, Engelholm L. Endoscopic management of cysts and pseudocysts in chronic pancreatitis: long-term follow-up after 7 years of experience. Gastrointestinal Endoscopy. 1989 Jan;35(1):1-9. https://doi.org/10.1016/s0016-5107(89)72677-8

9. Antillon MR, Shah RJ, Stiegmann G, Chen YK. Singlestep EUS-guided transmural drainage of simple and complicated pancreatic pseudocysts. Gastrointestinal Endoscopy. 2006 May;63(6):797-803. https://doi. org/10.1016/j.gie.2005.10.025

10. Binmoeller KF, Seifert H, Walter A, Soehendra N Transpapillary and transmural drainage of pancreatic pseudocysts. Gastrointestinal Endoscopy. 1995 Sep;42(3):219-224. https://doi.org/10.1016/s00165107(95)70095-1

11. Kahaleh M, Saumoy M, Arvanitakis M. Pancreatic fluid collections and necrosectomy with plastic stents versus lumen-apposing stents. Endoscopic Ultra- sound. 2017;6(9):132. https://doi.org/10.4103/eus. eus_80_17

12. Chen Y, Yang J, Friedland S, Holmes I, Law R, Hosmer A, Stevens T, Franco M, Jang S, Pawa R, Mathur N, Sejpal D, Inamdar S, Trindade A, Nieto J, Berzin T, Sawhney M, DeSimone M, DiMaio C, Kumta N, Gupta S, Yachimski P, Anderloni A, Baron T, James T, Jamil L, Ona M, Lo S, Gaddam S, Dollhopf M, Bukhari M, Moran R, Gutierrez O, Sanaei O, Fayad L, Ngamruengphong S, Kumbhari V, Singh V, Repici A, Khashab M. Lumen apposing metal stents are superior to plastic stents in pancreatic walled-off necrosis: a large international multicenter study. Endoscopy International Open. 2019 Feb 28;7(3):E347-E354. https://doi. org/10.1055/a-0828-7630

13. Yan L, Dargan A, Nieto J, Shariaha RZ, Binmoeller KF, Adler DG, DeSimone M, Berzin T, Swahney M, Draganov PV, Yang DJ, Diehl DL, Wang L, Ghulab A, Butt N, Siddiqui AA. Direct endoscopic necrosectomy at the time of transmural stent placement results in earlier resolution of complex walled-off pancreatic necrosis: Results from a large multicenter United States trial. Endoscopic Ultrasound. 2019;8(3):172. https:// doi.org/10.4103/eus.eus_108_17

14. Han D, Inamdar S, Lee CW, Miller LS, Trindade AJ, Sejpal DV. Lumen Apposing Metal Stents (LAMSs) for Drainage of Pancreatic and Gallbladder Collections. Journal of Clinical Gastroenterology. 2018 Oct;52(9):835-844. https://doi.org/10.1097/ mcg.0000000000000934

15. Kloska M, Hrad V, Aggarwal S, Shah S, Zator Z, Shah H. Endoscopic Ultrasound-Guided Drainage of Pancreatic Fluid Collections Using AXIOS Electrocautery Enhanced Delivery System a Retrospective Experience at a Large Quaternary Care Center. American Journal of Gastroenterology. 2019 Oct;114:S544. https://doi.org/10.14309/01. ajg.0000593272.21427.04

16. Venkatachalapathy S, Makin A, Pereira S, Johnson G, Bekkali N, Penman I, Oppong K, Nayar M, Carroll N, Godfrey E, Ryan B, Parihar V, McKay C, Huggett M. OC-073 The First Multicentre Experience from The UK and Ireland of the Use of the Hot Axios System for Transluminal Drainage of Pancreatic Fluid Collections. Gut. 2016 Jun;65(Suppl 1):A44.1-A44. https:// doi.org/10.1136/gutjnl-2016-312388.72 